\title{
From "unintelligent" to intelligent accountability
}

\author{
Sølvi Lillejord ${ }^{1}[$
}

Published online: 25 February 2020

(c) Springer Nature B.V. 2020

A moral being is an accountable being.

An accountable being, as the word expresses, is a being that must give an account of its actions to some other, and that consequently must regulate them according to the good-liking of this other.

Adam Smith, The Theory of Moral Sentiments, 1759 (1st Edition Part III, chapter 1)

Recent accountability reforms have distorted Adam Smith's interpersonal understanding of what it means, at its core, to be an accountable person. The ambitions behind this Special Issue are twofold: first, to show how the above enlightenment understanding of accountability has changed and culminated in existing dysfunctional systems and second, to build arguments for an alternative, more human accountability practice that strengthens the teaching profession. The Editorial describes why accountability systems emerge, whose interests they serve and what they are set up to achieve. It presents perspectives on the understanding of knowledge and society that underpins accountability systems, and which forms of rationality they support. As current systems favor investment in individual human capital, they tend to neglect social and cultural capital. There is an obvious need for accountability practices that are less technical, bureaucratic and ideology driven as teachers and school leaders feel caught in a one-sided system logic that overshadows essential parts of their job. The relationship between professions and accountability is discussed and arguments put forward for increased professionalization of teachers and educational leaders as a pivotal part of intelligent accountability systems.

\section{Introduction}

The term intelligent accountability was introduced by the British philosopher (O'Neill 2002, 2004, 2013a, b). She relates the current focus on accountability to a decline of trust in modern societies and questions the establishment of dysfunctional accountability systems with perverse consequences, for instance that most people do

Sølvi Lillejord

Solvi.Lillejord@uib.no

1 University of Bergen, Bergen, Norway 
not understand the system-generated information. Her solution is to develop a more intelligent accountability system with trust and transparency as the cornerstones. Since it was first introduced, researchers have referred to intelligent accountability (Andreasen et al. 2013; Cowie and Croxford 2007; Ellison 2012; Hodgson 2011; Ozga 2009; Sahlberg 2010) but the idea needs further elaboration. An ambition of the Special Issue is therefore to shed light on the general decline of trust in modern societies and provide empirical examples of how intelligent accountability can be conceptualized, operationalized and practiced.

Accountability is a 'global' term with a variety of connotations, interpretations and practices. It can be vertical (oriented towards compliance) or horizontal (when professions adhere to their societal mandate). Accountability has many faces and is described as a moving target (Kehm et al. 2009) or a slippery concept (West et al. 2011). Crooks (2003) found several rationales for accountability mechanisms in education. On an axis with low trust at the one end and high trust at the other, these rationales span those who assume that teachers will only do their job if directed and carefully monitored to those who believe that teachers are generally professional in their work and see external feedback as helpful. Along this axis, accountability is an umbrella term; perceived and practiced differently as it ranges from a distrustful, policing (unintelligent) vision of accountability to a more collegial and formative one.

There is a family likeness between accountability, evaluation and assessment, and ample evidence that how we assess, evaluate and hold people accountable has both short- and long-term consequences. To show how evaluations can be practiced in ways that are-not necessarily by intention, but certainly by result-productive or re-productive, un-productive, and even counter-productive for learning and improvement — both at individual and system levels, Lillejord and Dysthe (2008) use Bakhtin's concepts of dialogism and monologism. While dialogism is polyphonic and explains how people jointly construct and transform knowledge through multiple perspectives, monologism is the authoritative word, one-way transmission of knowledge external to the individual.

Weiss (1972) labelled evaluation an elastic word that stretches over judgments of many kinds. Emphasizing the social purpose of evaluation, she argued that evaluation must start with use in mind. Articles in this special issue question the rationales behind current accountability reforms and confirm that they are also used to name, shame and blame teachers and schools (Elstad 2009).

Since the 1980s, education policy has presented global, generic problems and introduced ideological solutions to these problems (Ball 1998). While accountability has been a favoured solution, the term is used with few specifications of who should be accountable for what, how - and why. Instead, proponents of accountability present it as an abstract moral dictum, a dehumanised guarantor for transparency and public quality control. This abstractness was noted by O'Day (2002) who asked why the school was the unit of intervention, despite the fact that implementation relies on individual actors, and Cochran-Smith et al. (2017), who found that teacher education was held accountable, based on evaluation and monitoring of outcomes related to institutions and programs. The last decennia, researchers have documented many examples of malpractices in accountability systems that fail to take knowledge 
development and learning into consideration (e.g. Berliner 2011; Darling-Hammond 2007; Thiel 2019; Meadows and Black 2018; Webb 2006).

Elmore $(2002,2006)$ described accountability in education as a complex mix of pressure and support and highlighted two problems of accountability systems: They have neglected the knowledge-generating part of the process and policymakers assume skills and infrastructures that are lacking in educational systems. Politicians expect schools to do things they don't know how to do, with no support structure. This was confirmed by Hatch (2013) who found that follow-up mechanisms were not in place when Norway introduced national tests and monitoring.

Based on this, intelligent accountability must formatively aim for improvement, systems must generate knowledge that is intelligible and can be used for improvement purposes and practitioners must have the appropriate skills.

This Special Issue of the Journal of Educational Change problematizes what happens when accountability is performed as an audit (Strathern 2000) and presents alternatives to coercive (Shaw and Wright 2000) and unintelligent (O'Neill 2002) forms of accountability. The collection of articles produces profound insights into the complexities of accountability practices and shows alternatives to accountability systems that too often hamper individual and system growth and disempower school professionals instead of strengthening the teaching profession. The Special Issue suggests a more intelligible accountability that builds professional responsibility through knowledge-enhancing practices.

\section{A neoliberal hostile takeover}

According to O'Neill (2002) the introduction of current accountability systems reflects a general, politically driven distrust that erodes education systems. Here, the launch of the report A Nation at Risk in 1983, commissioned by the US President Ronald Reagan and followed by the election of Margaret Thatcher as Prime Minister in the UK, 1979 serve as a starting point. Under Reagan and Thatcher, liberal politics turned neoliberal with a central characteristic being the application of the logic and rules of market competition to the public sector (Olssen 2016). This turn was labelled a hostile takeover due to its anti-unionism (Anderson 2006); the idea that marketplace competition models would eliminate 'inferior' schools through natural selection (McCarthy 1997); and its allowance of a consumer-driven, free choice and market approach to supersede the democratizing function of public schools (Lytle 2013), which gave the elite control over education through the charter school movement (Scott 2013). To this, Stephen Ball (2010) adds the commodification of educational knowledge, with educational policy as a profit opportunity.

Walzer (2007, p. 53) explains liberalism as an 'art of separation' or a 'world of walls', where each wall creates new liberties for people - the most famous being the wall between church and state. Whereas the individual in classical liberalism was understood as a free and autonomous human being, in neoliberalism the (weakened) state seeks to create an individual that is an enterprising and competitive entrepreneur (Olssen 2016). This shift was described as a neoliberal fallacy (Przeworski 1992); a great ideological experiment that offers a magic elixir, a mixture of 
privatisation and marketisation, which will cure all ills. Central to Walzer's argument is that the liberating force he labels the 'art of separation' never intended to build fences between individuals, but to set people free through a process of separating institutions, practices and relationships of different sorts. Men and women are free when they live within autonomous institutions with institutional integrity, but people are not liberated when separated from their fellow beings: "Lines encircle churches, schools, markets and families—not you and me" (Walzer 2007, p. 63).

As the articles in this Special Issue show, this neoliberal fallacy has had worldwide detrimental effects on public education as it was embraced by politicians from a broad spectrum of parties. Corporate managers' main goal is return on investments (ROI) for their shareholders. To achieve this, they establish standards of excellence, use incitements and competition strategically so that the best win and are rewarded. When the simple logic that competition enhances ROI was applied to schools, education's dual purpose of supporting individual learning and well-being and ensuring a skilled work force was lost. Neoliberal policies reduced education to students' measurable learning outcomes and held schools accountable for students' learning growth (ROI).

\section{Fear-driven education policy and the soul of education}

Having recovered from the 1957 Sputnik-shock, a new competitive threat to the US emerged in East-Asian economic dynamism and economic forecasts indicating that Asian countries preferred trading with Japan instead of the US (Kwan 2004). When Japan in the late 1980s replaced the USA as the world financial leader, this new fear materialized as a 'Yen-shock' (Burstein 1990). The Tokyo Stock Exchange surpassed New York (NYSE), and nine of the world's 10 largest banks were on Japanese hands. The massive investment in US education that followed the Sputnik-shock could not be repeated in the 1980s when neoliberal politicians called for increased productivity in public sector institutions, such as schools, that were 'protected' from market competition.

A Nation at Risk (National Commission on Excellence in Education 1983) introduced a strong sense of urgency to the education policy discourse. The report's conclusions were surprisingly negative (Bell 1993), and remedies suggested were surprisingly traditional. The commission argued that the U.S. pre-eminence in commerce, industry, science and technology was lost in a rising tide of mediocrity. Blaming schools for the recession in the U.S. economy (Hursh 2007), the report recommended emphasis on basic skills, more homework, and competence development. This sentiment of fundamental distrust in the school system, educational leaders, teachers and teaching was, along with the 'new' remedies, quickly picked up (Halpin and Troyna 1995), and circulated globally (Popkewitz 1996). As part of the rapidly spreading neoliberal policy agenda, U.S. Federal States responded with legislative actions and accountability directives, and in England, the Conservatives delegitimized teachers and their unions through discourses of derision (Ball 1990). In 2001, President G. W. Bush by law (No Child Left Behind) made accountability the centerpiece of the agenda to improve education. The legislation's theory of change 
suggests that schools can increase student achievement through a program of yearly standardized testing that informs accountability ratings, ignites sanctions for poor performance, and motivates local improvement responses (O'Day 2002). Tests are used to hold teachers and school administrators accountable for students' learning outcomes and as levers to change classroom instruction. These policies have been continued with cross-party political support.

When the Organization for Economic Co-operation and Development (OECD)countries were struck by the Programme for International Student Assessment (PISA)-shock in 2001, the decoupling of education from Bildung and the recoupling of learning to economy was accomplished. Bildung is, according to Herdt (2019), a complex German term with no direct equivalent in English. It is an ever-unfinished project, cosmopolitan at heart, with elements of formation, cultivation, and shaping. In line with liberal education it aims to broaden our minds. Bildung is rooted in Enlightenment ideals of freedom and liberation and understands education as the task of forming humanity. It sees education and learning as inseparable from the content of what is learned and has connections to the Greek Paideia and Roman Humanitas. The person of Bildung was not just educated, but capable of sound judgement. As a competent person, she could demonstrate civil courage and take responsibility for her own life rather than leaving this in the hands of paternalistic authorities. For generations, the Bildung tradition has, fundamentally, constituted teachers' understanding of the soul of education in the Nordic countries and in Continental Europe.

The fierce reactions to PISA 2001 can, argued Tröhler (2009), be a cultural clash between the national taken-for-granted assumptions about education and the transnational agenda of OECD experts who continuously remind politicians that they are not necessarily in control and that their return on investment is insecure. All member states are advised to remain at 'the head of the pack' in terms of innovation and change (OECD 1994a, b, p. 3).

Kotz (2009, p. 307) blamed what happened during the financial crises in 2008 on the following features of neoliberal capitalism: (a) deregulation of business and finance (more "free" market); (b) privatization of state services; (c) reduction in social spending, (d) reduction of taxes on businesses and wealthy individuals: (e) attacks on trade unions; (f) fewer long-term employees, more part-time workers; and (g) unrestrained, cut-throat competition. The slow reaction to the aftermath of the recession that affected some groups more than others and the combined effect of these features rapidly tore the social fabric apart. When state support and safety-nets disappear, people's sense of fairness, predictability, stability and solidarity vanish, and their trust in systems and other people evaporates.

Fear, says Bude (2018), is in its substance infinite. He contrasts the fear absorption strategy used by Franklin D. Roosevelt when he in March 1933 declared: "the only thing we have to fear is fear itself" to how Nazi Germany at the same time turned "the rumble of fear into the engine of a new age" (p. 4). He refers to Luhman (1989), who identified anxiety as perhaps the only a priori principle in modern society. While fear typically is object-oriented, anxiety is fear about what might happen. It springs from the knowledge that everything is open, but nothing is meaningless and that the threat of exclusion never ends. 
After 30 years of neoliberalism, the middle-class has grown apart in a variety of milieus, thus affecting traditional middle-class needs for predictability and stability and support for public education. The creative class, urban clusters of talented and creative people, the human capital that powers economic growth, now accounts for about half of all US wages and salaries (Florida 2014). Many are in finance, fashion, art, consulting, and technology. They see creative destruction (Reinert and Reinert 2006) as an opportunity, not a tragedy, and have little concern for those who fail. There is a growing social divide between the few successful individuals with top bonuses who dominate the game and the many aspiring people.

Asking how a spreading "winner-takes-it-all"-mentality affects the mood of society, Bude (2018) positions education as a signal issue related to the anxieties of the middle class. After the PISA-shock in 2001, many families worried their children were no longer in good hands in the public education system. A language of competencies that has emerged in the wake of international comparative studies, signals that parents' most important worry is "where will my child be primed-cognitively and communicatively, mentally and motivationally, emotionally and expressivelyfor an uncertain future in an uncertain world?" (Bude 2018, p. 56). Middle-class parents who hope for the best for their children feel that they are left alone in the struggle to find the 'right' kindergarten, school, and university (Kosunen and Carrasco 2016) — and they can never be certain. This kind of uncertainty opens a niche for market actors, who know how to transform needs into products. It is also in keeping with the neoliberal agenda for a shrunken state and more private competition.

\section{The rise of an Epistocracy}

The twentieth century was largely influenced by scientific engineering ideals and technocracy, and so is the fear-driven educational policy that underpins accountability reforms and reflects the US fear of being dethroned as the world leading economic power. It gains support from dwindling empires, aspiring empires and nation states who all want to be on the winning team. When introducing business logic in schools, neoliberal policies narrowed their raison d'être to measurable learning outcomes, skills and competences, accompanied by a strong belief in the cleansing waters of competition (Hess 2001) and that the best will thrive when offered merit pay and put under pressure.

An increasingly more important policy vehicle in this development is the OECD, promoting a vision of education as an investment in human capital to be mobilized when member states face social challenges and problems related to economic growth (Ydesen 2019). Following business logic, they encourage politicians to invest in the nation's human capital. The return on investment is growth in learning outcomes as measured through tests. Comparisons and free choice between public and private providers are used to fuel competition between schools and nation states. In the long run, good institutions win and blossom, poor institutions disappear in the "marketplace' constructed by these parameters. With the support of the member states, the OECD is now casting itself as a global bureaucratic Epistocracy. Funded by member states they run comparative tests that yield the information needed to formulate a 
diagnosis. They then take on the role of educational experts, assist member states in the analysis of the test-generated numbers and prescribe the medicine. They write country reports and act as consultants, assisting countries on how to apply general and global advices in local contexts. They are in a vantage position to inform policymakers about how far-away countries successfully have solved their problems and advise all on where their money is best spent. In this technocratic, closed circuit of reasoning, the slogan appears to be 'keep it simple'. Education must, however, be understood and treated as a highly complex system.

\section{Human, social and cultural capital}

While knowledge has always been a crucial resource in the economy, Lundvall (1998) points out that in the learning economy, knowledge is the most important strategic resource with human capital as the most rapidly growing production factor.

Despite bitter criticism since the idea was launched in the 1950s, neoclassical human capital theory has rapidly expanded its influence into education policies (Tan 2014). It draws on rational choice theory and positions education as the source of economic development. Human capital theory is embraced and defined by the OECD as the knowledge, skills, competencies and attributes embodied in individuals that facilitate the creation of personal, social and economic well-being (Keely 2007). Education is both seen as an investment in individuals and the key to member countries' economic growth. The latter assumption rests on far less secure foundations than is widely supposed and has generated simplistic policies with deleterious effects (Wolf 2004). Unlike moral theory, rational choice theory assumes that individuals seek to maximize their own interests by making optimal decisions to achieve his or her aims (Elster 2016). In this tradition, intelligent action can be understood as smart action, including actions intended to outsmart others. Mainstream economists depict Homo economicus as a self-interested, labor-averse, and utility-maximizing rational agent (Tan 2014, p. 417). Those who, with minimal effort maximize their own interest the most, win the game.

When developing social capital conceptually, Coleman (1988) argued that a weakness of rational choice theory is that it assumes free movement and ignores the fact that people are restricted, redirected and shaped by their social context. He therefore introduced social structure in the rational action paradigm and examined three forms of social capital, (a) obligations and expectations, (b) information channels and (c) social norms. He argues that social capital, unlike other forms of capital, inheres in the structure of relations between actors and uses Jewish wholesale diamond vendors in New York to exemplify how social capital 'works'. Central to the functioning of this market is trust-based free exchange of stones for quality inspection. In the process of negotiating a sale, a merchant will give another a bag of expensive stones to be examined in private, with no formal insurance that stones will not be substituted with more inferior stones or replica. Obviously, anyone who violates these rules, is no longer a trustworthy member of the group.

Bourdieu (1989) distinguished between economic, cultural, social and symbolic capital and argued that social reality could be understood as a system of relations 
between actors, who are distributed in the social space according to the volume and relative weight of the capital they possess. He used school diplomas and university degrees as examples of symbolic capital and argued that cultural capital is an evolving resource, distinct from measured skills or ability. In this perspective, social and cultural capital are available resources to be utilized by those who know how to use them.

Education policy has, the last decennia, been dominated by educational economists, who maintain the rational choice-based, individual human capital perspective that tends to ignore the dynamism in horizontal relations between people and the productive potentials of social and cultural capital. Through this reductionist move, important aspects of values, social and cultural learning are lost. To better understand the driving forces of this development, it is relevant to ask how sociologists have described societal forms of rationality, social actions and interactions.

\section{Theories of human action and interaction}

German sociologist Tönnies (1887/2001) found two distinctively different categories of human interaction and collaboration in modern societies. He labelled one category of social ties Gemeinschaft, and the other Gesellschaft. Interactions between people in Gemeinschaft (community) are dominated by close personal ties, mutual trust and joint understanding. Interactions between people in Gesellschaft (society) are indirect and characterized by loose, impersonal ties, formal interactions and potential distrust. Relations in Gesellschaft are not trusting, and exchanges of services typically are accompanied by transactional expectations of gains. While interactions in both Gemeinschaft and Gesellschaft are social and the borders between them blurred, the significant difference lies in the boundary line separating the personal and the impersonal.

Qualitatively different forms of human interactions were also identified by Max Weber (1947), who distinguished between purpose-rational action characterized by Zweckrationalität or means-end-rationality (which would be typical for actions in Gesellschaft) and value-rational action characterized by substantial values and norms (typical for Gemeinschaft). Weber's point was that in practically every domain of modern culture and society-including education-there is a relentless movement towards Zweckrationalität, instrumental means-end rationality. In its pure form, this rationality risks turning schools into 'iron cages', which threaten the development of autonomous individuals.

Habermas (1987) has distinguished between the Lebenswelt, or lifeworld, with traits similar to Gemeinschaft, and the Systemwelt, which is similar to Gesellschaft. Habermas argued, not unlike Weber, that in modern societies a colonizing process is taking place as instrumental and strategic forms of system-rationality are increasingly applied in people's lifeworld.

People balance the taken-for-granted personal relations of trust that reside in closelyknit Gemeinschaft/Lifeworld communities with the precautionary approaches needed when they engage in the impersonal relations of Gesellschaft/System. We speak more freely to family members than to strangers and often expect more support from those 
close to us than from others. Ideally, the school should bridge the divide between these two domains of life, with different rationalities, and help children gradually master the different and ambiguous expectations they meet in modern, complex societies. Institutions that bridge state and family functions are precious for human co-existence and democracy as they provide children with a common ground where they learn how to relate to others, learn to "read" abstract information and to balance the personal and the impersonal.

Accountability systems lack this balance as they generate knowledge in a format that is not easily translated into actionable knowledge (Cross and Sproull 2004; SteinerKhamsi 2013). There is a distance between those who design the systems and those who are expected to act upon the system generated knowledge. The need to bridge this distance can explain the rapid growth of globally circulating experts who "assist" practitioners who need translators to understand what they are expected to do. In this fight over who "owns" the knowledge, knowing that takes prominence over knowing how (Ryle 1945), or in a platonic sense, episteme over doxa.

\section{Paradoxes of accountability reforms}

By design, accountability systems have narrowed the scope of education. The emphasis on standards, comparisons and measurable learning outcomes positions the Bildung tradition as outdated. When politicians ignore the importance of social fabric and place students, schools and nations in relationships of competition, people are separated from each other and the capacity-building power of mutual learning is lost. Paradoxically, the weakening of the productive potential of social and cultural capital hits hardest those students who need it the most (Salloum et al. 2018).

Reinert and Reinert (2006) argue that a crucial problem in standard economics is its focus on exchange - supply and demand - rather than on production. From this arises the paradox that when ROI is the prime goal and improvements expected to be achieved through calls for back to basics (Jordan 1995), policy enhances reproductive practices such as testing what students have already learned instead of supporting their productive learning potential. The application of market economic ideas that reduce schooling to input-output and increased ROI is therefore counterproductive for education.

The greatest paradox of accountability reforms is, however, that children with low social and cultural capital typically struggle the most in the pursuit of human capital. As accountability reforms ignore the dual function of education, they are not designed to compensate those students who desperately need to learn how to balance the different types of rationality underpinning modern society (as described by Tönnies, Weber and Habermas) and how to benefit from available social and cultural capital.

\section{Brief presentation of the articles}

O'Neill's critique of existing accountability reforms is that indicators may be misleading due to inaccuracy; that comparative rankings do not reveal anything fundamental about education quality; that the information generated through 
accountability systems is not understandable for the general public and that the current preoccupation with accountability comes as a result of a decline in societal trust. These problems are discussed in the nine papers included in the special issue, and they are briefly presented here, guided by four questions: Who informs the policymakers? Which assumptions about knowledge and skills underpin accountability reforms? How impartial and "fair" are accountability systems? and Is accountability as slippery concept and a moving target?

\section{First question: Who informs the policymakers, and whose interests are served?}

The first two articles (Ozga, Ydesen and Bomholt) problematize the OECD's development into a global governing complex (Ydesen 2019). They question the knowledge base that the OECD offers member states, ask whose interests are best served by OECD initiatives and whether OECD advices contribute to strengthening schools and educational systems.

Ozga draws on findings from research that she carried out with colleagues in European countries between 2000 and 2017. To investigate how education is governed in globalizing times, she focuses on: (1) the growth of education as a key policy field in Europe; (2) the growth of regulatory instruments (data) and (3) the work of national and transnational policy actors in 'doing' governing. She problematizes the technical-managerial accountability that is a result of large-scale transnational, comparative surveys, such as PISA, and argues that these systems generate a new form of knowledge that is presented as indisputably true in a monolithic sense, to be taken for granted and not contested. Contrary to scientific authority that arises from debate and dispute, this knowledge is presented as given, not as something that can be questioned and challenged.

As a simplified regulatory tool, the system works to shift authority from politicians to non-governmental actors, especially external experts, commercial agencies and consultants. This happens because the authoritative "truth" of performancerelated data is not self-evident and needs interpretation. Most people don't understand the system generated numbers and figures or how they are produced-by this so called "transparent" system. Ozga concludes that as technical-managerial accountability erodes and conceals politics, it also enables a technocratic elite to accrue power and influence in education, to profit from its provision, and to pursue political agendas that appear neutral, objective and necessary, but that also strengthen bureaucratic control and disempower teachers.

Based on an analysis of 165 archived documents, in the OECD (Paris) and in Australia, Ydesen and Bomholt use the implementation of accountability systems in Australia in the 1970s as a case to understand the nature and makings of accountability reforms. The OECD's economistic work towards educational accountability started in the 1960s, driven by the question of ROI. The Australian case reveals interesting internal discussions about accountability. While some of the stakeholders believe that the purpose of schooling extends far beyond a country's economic development, others put their trust in numbers. The debate addresses the controversial 
and ambivalent nature of indicators that constitute a very powerful technology in terms of governance and can be used with very different consequences. How indicators are used is decisive as their use can build or erode trust.

From an intelligent accountability perspective, the main goal is to build trust among all the stakeholders. Ydesen and Bomholt therefore conclude that balance between input and output is essential if accountability systems are to be regarded as fair by those who are expected to generate the improved outcomes. Continuous focus on input is vital to keep decisions-makers responsible for the provision of resources, staff, competence development and working conditions. As indicators play such a vital role, a fundamental condition for achieving trust is a high level of assessment literacy. Therefore, a co-creation approach to the development of accountability practices can serve to maintain a fair balance between input and output.

\section{Second question: Which assumptions about knowledge and skills underpin accountability reforms?}

In the second group, four articles show how policy assumptions generate problems "on the ground" as teachers, school- and district level leaders don't necessarily have the knowledge and skills that is assumed by policymakers.

Tolo, Lillejord, Petour and Hopfenbeck have reanalyzed data from a large-scale national program intended to implement Assessment for Learning in Norwegian schools. Analyzes of qualitative data reveal differences in how school leaders approach the implementation process. Some school leaders appeared to trust their teachers' knowledge, competence and work processes blindly and left them with the responsibility for program implementation. Other school leaders mistrusted the teachers and instead trusted the program's external experts. These leaders' lack of trust teachers was related to the fact that they experienced teacher resistance and little support from district administrators. In these schools, relations of distrust therefore complicated implementation and led to the abdication of school leaders. In a third category, school leaders took a knowledge-based and inquiring approach to the implementation process. They both trusted and challenged the teachers and actively engaged in collaboration in order to strengthen their professional work. Analysis of the relationship between school leaders and district level administrators also showed a mixed picture. Some school leaders experienced little or no support from the local administration, others were quite pleased with the local collaboration. The article concludes that the balanced leadership approach, where teachers are both challenged and supported, is the most promising.

Lillejord and Børte build on a systematic review on working conditions and training needs for middle leaders in school. The review reveals that 50 years of research consistently shows that middle leaders have quite trivial jobs. For decades, researchers have asked if this is the optimal use of human resources and repeatedly suggested that instead, middle leaders should be instructional leaders. Why this shift is so slow is, however, somewhat unclear. An NVIVO analysis of the 37 included articles revealed that school middle leaders rely on experience as their only knowledge source and that research is barely mentioned. Middle 
leaders' job is often not in the organizational chart and they frequently get their daily tasks personally delegated by the principal, who both teachers, middle leaders and the principal perceive as the "real" leader. These findings are contrasted to how more mature professions typically synthesize knowledge from two sources when executing their professional discretion: acknowledged good practice and research. Delegation of discretionary power comes with a demand for accountability, and professions are expected to 'account' for their judgments and decisions. As professions typically build their leaders from within through specialization and qualification, the article concludes that systematic efforts to strengthen the teaching profession can support the development of middle leaders as instructional leaders.

Over a period of 3 years Datnow, Lockton and Weddle have observed how 40 math teachers in four low performing schools engage in data team meetings. Based on $180 \mathrm{~h}$ of observational data and 128 interviews with teachers and school leaders they investigated how accountability influences patterns of collaboration and the schools' meeting routines. They found that test scores dominated the discussions and that accountability was highly present in the meetings. When school leaders asked teachers to use data to target students in need of intervention, the idea of "targeting" students did not make sense to teachers, who felt they always worked most with the neediest students, anyhow. Both teachers and school leaders contributed to pushing the discussion in the direction of accountability. As teachers' prime concern was whether they had completed the task at hand, they "worked" the agenda to be certain they got their things done, and everything in the system logic pointed them towards teaching to the test. Datnow et al. find that educators were caught in a double bind in a system with inherent contradictions. The pressure for quick improvements in test scores pushed teachers towards bureaucratic compliance, and trust between teachers and school leaders was not always evident in the observed schools.

In a study from Ontario, Canada, Brown studied the implementation of a "Dialogic Model of Impact" (DMI), designed to evaluate the Renfrew County Catholic District School Board's 'Through their Eyes' approach to teaching and learning in kindergartens. Based on data from 10 interviews with district and school leaders and focus group interviews with 20 teachers, the study shows that teachers who collaborated developed new forms of assessment and the confidence to use digital technology as a teaching and learning tool. This enabled them to pass on information regularly to parents about their children's progress.

Principals, however, were initially unable to identify if their teachers were using the digital technology effectively and could therefore not support teachers' work. To assist the implementation process, a Maturity Matrix was introduced that enabled principals both to see where impact was being made and the areas where support was required. Based on evidence that adaptive translation (Brown and Flood 2018) is more supportive for teachers' professionalism than strict implementation fidelity, Brown concludes that adaptive translations are more intelligent because they liberate teachers from technical demands that are not well-aligned with their pedagogical work situation. 


\section{Third question: How "impartial" and "fair" are accountability systems?}

Using Chile and South Africa as examples Petour and Assael and Ehren, along with Baxter and Paterson, frame accountability in the global South from a social justice perspective. The authors identify challenges and argue for the development of more intelligent accountability systems that improve learning and promote social justice in their countries.

Petour and Assael contrast the principles that sustain the positive rhetoric around results-based accountability, namely transparency, responsibility and improvement, to three dimensions of social justice: distribution, recognition and participation. They find that transparency or sharing results publicly, has stigmatized public schools that serve disadvantaged students. These schools now experience a more intense level of pressure for improved results. Attempts to hold schools responsible through external control has created a gap between what teachers and schools perceive as valuable learning and those promoted by external accountability policies. Because the intention of formative assessment is unfulfilled, information generated through the accountability system is difficult to use in daily classroom practice.

The authors conclude that an intelligent and socially just accountability system must build on the firm principles. For example, formative purposes should be given priority above control; external control should be replaced by trust and responsibility; participation should be a requirement of accountability policy formulation; external test-based strategies should be replaced by school-based assessment systems; and difference and diversity should be integral to assessment design.

In a study from South Africa, Ehren, Baxter and Paterson find that the distribution of resources still privileges white South Africans. Teacher unions therefore question the fairness of the accountability system. Lack of trust seems to inhibit the implementation of effective accountability as teacher unions reject school inspections and block the publication of assessment data. A returning question is: Can accountability build trust-or does it contribute to distrust? Using the concepts competence, benevolence and integrity as analytical tools, Ehren et al. identify these counter-productive aspects of the accountability system: District level administrators are appointed on political affiliation instead of merit; there is an overload of reporting requirements and a constant change in policy priorities with many goals and outcomes that are unmanageable to implement or monitor. When policies are never fully implemented, it leads to a sense of fatigue or indifference amongst the teachers. One-sided accountability (poor coordination, weak bureaucratic accountability and little professional accountability) leads to distrust. When those who are held accountable are not provided with resources to meet accountability expectations, trust relations break down and trust in the system evaporates. 


\section{Fourth question: Is accountability a slippery concept and moving target?}

Deem and Baird discuss problems inherent to the accountability system Higher Education Teaching Excellence Framework (TEF). They explore the driving forces behind the introduction of (TEF) in England, outline how it works and some of its consequences and find both unintended and intended negative consequences that can be ascribed to the system's double purpose: to assess teaching excellence and serve as a mechanism for constructing a market in UK higher education. They also analyze the underpinning ideologies and logics of choosing metrics to assess teaching excellence, in determining Gold, Silver and Bronze TEF outcomes and introduce the notion of TEF as an index rather than a measure. They conclude that TEF is less about improving teaching but rather an endeavor to pit universities against each other in a marketized competitive system, in which student debt levels are rising fast. Also, TEF is ideologically and somewhat arbitrarily driven in relation to its metrics and does not follow most of the recommendations of the research on assessing teaching excellence or high-quality teaching. Somewhat paradoxically, the TEF looks set to become part of the HE landscape in England for the fore-seeable future, even though it scarcely measures teaching excellence and relies on remote judgments and convenient metrics, not visits to institutions to inspect and observe the teaching of those HEIs awarded Gold.

\section{Conclusion}

The logic behind standards-based accountability reform appears deceptively simple (Elmore 2000): Schools and school systems must be held accountable for their contributions to student learning. Standards indicate what students should know and be able to do. Administrators at state-, district and school level should regularly evaluate teachers' teaching and check if students learn what they are expected to learn. Evidence from evaluations of teaching and student performance should then be used to improve teaching and learning and allocate rewards and sanctions.

This Special Issue shows that neither schools nor education systems are as simple as assumed in accountability reforms, modelled on the market logic of corporate businesses.

Accountability systems have inbuilt contradictions that pose problems for those who are being held accountable. Teachers find themselves in a double-bind situation as impersonal system-rationality tend to colonize their professional discourse. The knowledge generated through accountability systems is foreign to many teachers who don't know how to translate it into actionable knowledge. Leadership support appears to be random and administrators who act as liaisons use concepts that are not recognizable for teachers. While accountability systems are presented as transparent, they appear opaque for those who are being held accountable. 
An even bigger problem is that knowledge generated through accountability systems is presented as given and indisputably true. This distinguishes it from scientific knowledge that is perceived as fallible and therefore systematically questioned and contested. Following the introduction of accountability reforms around the turn of the century, the OECD has grown into an epistocracy, with the prime goal to advice member states on where their money will yield the largest ROI. Their advices are based on carefully selected evidence about what works or has effect. This kind of monolithic, autocratic truths appear effectively immune to scientific testing and democratic deliberations. As elegantly summed up by Bakhtin, the authoritative word demands that the listener acknowledges it unconditionally. It does not demand free reflection about its content, but 'our unconditional allegiance' (Bakhtin 1981, p. 343).

Combined with neo-liberal policies and a fear-driven education policy modelled over corporate businesses that are not nearly as complicated as schools, these systems are of little help for teachers and school leaders who work to educate new generations for independent lives and active, democratic participation in an increasingly complex world.

As practice, accountability should be about how teachers and administrators at school and district level collaboratively analyze results with the ambition to improve their practice and students' educational outcomes. To succeed, teachers and leaders must understand the information generated through the accountability systems and know how to translate the system-generated information (data) into actionable knowledge. School leaders, administrators and teachers therefore need two competences: (a) knowing how to interpret data and (b) understanding how they can integrate the system-generated information in practice.

An intelligent accountability system must be perceived by all participating actors as fair and just. It must be an interpersonal system that is based on dialogue, participation and co-creation. It should be characterized by mutual understanding between teachers and leaders at all levels, who jointly work towards the same goals. For accountability to be intelligent, people must be accountable to someone-there must be human beings at both ends of the system. The foundation of intelligent accountability in education is that teachers and school leaders regularly and systematically use research and acknowledged good practice in their everyday work. Like other professions, the teaching profession must collectively and regularly question existing practices, adjust them according to new research and societal developments and aim at continuous improvement. A strengthened, ambitious teaching profession will be in a position to hold itself accountable to the students, parents and society it serves.

Money that is now spent on external experts should instead be invested in teacher education and the teaching profession.

Acknowledgements Open Access funding provided by University of Bergen. This Special Issue on Intelligent Accountability was developed through two Symposia arranged in cooperation between the Center for the Science of Learning and Technology (SLATE) at the University of Bergen, Norway, the Norwegian Knowledge Centre for Education and the Oxford University Centre for Educational Assessment (OUCEA) at the University of Oxford, United Kingdom. The editorial is written with valuable input and comments from the Special Issue's Guest Editors Professor Jo-Anne Baird, Head, Department of 
Education, Oxford University, UK and Associate Professor Astrid Tolo, Head, Department of Education, University of Bergen, Norway.

\section{References}

Anderson, N. (2006). Hostile takeover: Antiunionism and the neoliberal politics of urban school reform in New York. WorkingUSA, 9(2), 225-243.

Andreasen, K. E., Rasmussen, A., \& Ydesen, C. (2013). Standardized testing. In J. Ainsworth (Ed.), Sociology of education: An A-Z guide (pp. 737-740). Thousand Oaks: Sage.

Bakhtin, M. M. (1981). The dialogic imagination: Four essays by M.M. Bakhtin, C. Emerson and M. Holquist (Eds). Austin, TX: University of Texas Press.

Ball, S. J. (1990). Politics and policy making in education: Explorations in policy sociology. London: Routledge.

Ball, S. J. (1998). Big policies/small world: An introduction to international perspectives in education policy. Comparative Education, 34(2), 119-130.

Ball, S. J. (2010). New voices, new knowledges and the new politics of education research: The gathering of a perfect storm? European Educational Research Journal, 9(2), 124-137.

Bell, T. H. (1993). Reflections one decade after a nation at risk. Phi Delta Kappan, 74(8), 592-597.

Berliner, D. (2011). Rational responses to high stakes testing: The case of curriculum narrowing and the harm that follows. Cambridge journal of education, 41(3), 287-302.

Bourdieu, P. (1989). Social space and symbolic power. Sociological Theory, 7(1), 14-25.

Brown, C., \& Flood, J. (2018). Lost in translation? Can the use of theories of action be effective in helping teachers develop and scale up research informed practices? Teaching and Teacher Education, $72,144-154$.

Bude, H. (2018). Society of fear. Cambridge: Polity.

Burstein, D. (1990). Yen!: Japan's new financial empire and its threat to America. New York: Ballantine Books.

Cochran-Smith, M., Baker, M., Burton, S., Chang, W. C., Carney, M. C., Fernández, M. B., et al. (2017). The accountability era in US teacher education: Looking back, looking forward. European Journal of Teacher Education, 40(5), 572-588.

Coleman, J. S. (1988). Social capital in the creation of human capital. American Journal of Sociology, 94, 95-120.

Cowie, M., \& Croxford, L. (2007). Intelligent accountability: Sound-bite or sea-change? CES Briefing No. 43, Centre for Educational Sociology, University of Edinburgh. Retrieved from http://www. leeds.ac.uk/educol/documents/174682.pdf.

Crooks, T. (2003). Some criteria for intelligent accountability applied to accountability in New Zealand. Paper presented at AERA (American Educational Research Association), Chicago, IL. April 22. 2003. Retrieved October 7, 2019, from https://www.fairtest.org/some-criteria-intelligent-accountabi lity-applied-a.

Cross, R., \& Sproull, L. (2004). More than an answer: Information relationships for actionable knowledge. Organization Science, 15(4), 446-462.

Darling-Hammond, L. (2007). Race, inequality and educational accountability: The irony of 'No Child Left Behind'. Race Ethnicity and Education, 10(3), 245-260.

Deem, R., \& Baird, J. A. (2019). The English teaching excellence (and student outcomes) framework: Intelligent accountability in higher education? Journal of Educational Change. https://doi. org/10.1007/s10833-019-09356-0.

Ellison, S. (2012). Intelligent accountability: Re-thinking the concept of "accountability" in the popular discourse of education policy. Journal of Thought, 47(2), 19-41.

Elmore, R. F. (2000). Building a new structure for school leadership. Albert Shanker Institute. Retrieved February 22, 2020, from http://www.shankerinstitute.org/sites/shanker/files/building.pdf.

Elmore, R. F. (2002). Bridging the gap between standards and achievement. Albert Shanker Institute. Retrieved from http://www.shankerinstitute.org/resource/bridging-gap-between-standards-and-achie vement. https://doi.org/10.1044/1059-0889(2002/er01).

Elmore, R. F. (2006). The problem of capacity in the (re)design of educational accountability systems. Paper presented at the conference "Examining America's commitment to closing achievement gaps". 
Teachers College, Columbia University, November 13-14, 2006. Retrieved from http://www.centerfore ducationalequity.org/events-page/equity-symposia/2006-examining-americas-commitment-to-closingachievement-gaps-nclb-and-its-a/papers/ElmoreCapacityPaper_10-5.pdf.

Elstad, E. (2009). Schools which are named, shamed and blamed by the media: School accountability in Norway. Educational Assessment, Evaluation and Accountability, 21(2), 173-189.

Elster, J. (2016). Sour grapes. Studies in the subversion of rationality. Cambridge: Cambridge University Press.

Florida, R. (2014). The creative class and economic development. Economic Development Quarterly, 28(3), 196-205.

Habermas, J. (1987). Lifeworld and system: A critique of functionalist reason. Volume 2 of the theory of communicative action. Cambridge: Polity Press.

Halpin, D., \& Troyna, B. (1995). The politics of education policy borrowing. Comparative Education, 31(3), 303-310.

Hatch, T. (2013). Beneath the surface of accountability: Answerability, responsibility and capacity-building in recent education reforms in Norway. Journal of Educational Change, 14(2), 113-138.

Herdt, J. A. (2019). Forming humanity: Redeeming the German Bildung tradition. Chicago: University of Chicago Press.

Hess, F. (2001). Tear down this wall: The case for a radical overhaul of teacher certification. Washington, DC: Progressive Policy Institute. Accessed October 31, 2019, from https://fordhaminstitute.org/natio nal/commentary/tear-down-wall-case-radical-overhaul-teacher-certification.

Hodgson, G. (2011). Creating a climate of intelligent accountability in all-through academies. Research Associate. Full Report. National College for School Leadership. Google Scholar.

Hursh, D. (2007). Assessing no child left behind and the rise of neoliberal education policies. American Educational Research Journal, 44(3), 493-518.

Jordan, B. (1995). Are new right policies sustainable? 'Back to basics' and public choice. Journal of Social Policy, 24(3), 363-384.

Keely, B. (2007). Human capital, how what you know shapes your life. OECD insights. Paris: OECD Publishing. https://www.oecd.org/insights/humancapitalhowwhatyouknowshapesyourlife.htm.

Kehm, B. M., Huisman, J., \& Stensaker, B. (2009). The European higher education area: Perspectives on a moving target. Rotterdam: Sense Publishers.

Kosunen, S., \& Carrasco, A. (2016). Parental preferences in school choice: Comparing reputational hierarchies of schools in Chile and Finland. Compare, 46(2), 172-193.

Kotz, D. M. (2009). The financial and economic crisis of 2008: A systemic crisis of neoliberal capitalism. Review of Radical Political Economics, 41(3), 305-317.

Kwan, C. H. (2004). Yen bloc: Toward economic integration in Asia. Brookings Institution Press. Retrieved December 28, 2019, from https://www.brookings.edu/book/yen-bloc/.

Lillejord, S., \& Børte, K. (2019). Middle leaders and the teaching profession: Building intelligent accountability from within. Journal of Educational Change. https://doi.org/10.1007/s10833-019-09362-2.

Lillejord, S., \& Dysthe, O. (2008). Productive learning practice. A theoretical discussion based on two cases. Journal of Education and Work, 21(1), 75-89.

Luhman, N. (1989). Ecological communication. Cambridge: Polity.

Lundvall, B.-Å. (1998). The learning economy: Challenges to economic theory and policy. In K. Nielsen \& B. Johnson (Eds.), Institutions and economic change: New perspectives on markets (pp. 33-54). Cheltenham: Edward Elgar, Firms and Technology.

Lytle, J. H. (2013). Philadelphia school district deconstruction-A case requiring consideration. Penn GSE Perspectives on Urban Education, 10(1), n1.

McCarthy, M. (1997). 8. School privatization: friendly or hostile takeover? Journal of Education Policy, 12(1-2), 61-69.

Meadows, M., \& Black, B. (2018). Teachers' experience of and attitudes toward activities to maximise qualification results in England. Oxford Review of Education, 44(5), 563-580.

Olssen, M. (2016). Neoliberal competition in higher education today: Research, accountability and impact. British Journal of Sociology of Education, 37(1), 129-148.

O'Neill, O. (2002). A question of trust: The BBC Reith lectures 2002. Cambridge: Cambridge University Press.

O’Neill, O. (2004). Accountability, trust and informed consent in medical practice and research. Clinical Medicine, 4(3), 269-276.

O'Neill, O. (2013a). What we don't understand about trust. Retrieved February 22, 2020, from https://www. ted.com/talks/onora_o_neill_what_we_don_t_understand_about_trust.

O’Neill, O. (2013b). Intelligent accountability in education. Oxford Review of Education, 39(1), 4-16. 
O’Day, J. (2002). Complexity, accountability, and school improvement. Harvard Educational Review, 72(3), 293-329.

OECD. (1994a). The OECD jobs study—Facts, analysis, strategies. Paris: OECD.

OECD. (1994b). The OECD jobs study—Evidence and explanation, Part I. Paris: OECD.

Ozga, J. (2009). Governing education through data in England: From regulation to self-evaluation. Journal of Education Policy, 24(2), 149-162.

Ozga, J. (2019). The politics of accountability. Journal of Educational Change. https://doi.org/10.1007/s1083 3-019-09354-2.

Popkewitz, T. S. (1996). Rethinking decentralization and state/civil society distinctions: The state as a problematic of governing. Journal of Education Policy, 11(1), 27-51.

Przeworski, A. (1992). The neoliberal fallacy. Journal of Democracy, 3(3), 45-59.

Reinert, H., \& Reinert, E. S. (2006). Creative destruction in economics: Nietzsche, Sombart, Schumpeter. In J. Backhaus \& W. Drechsler (Eds.), Friedrich Nietzsche (1844-1900) (pp. 55-85). Boston, MA: Springer.

Ryle, G. (1945). Knowing how and knowing that: The presidential address. In Proceedings of the Aristotelian society (Vol. 46, pp. 1-16). Aristotelian Society, Wiley.

Sahlberg, P. (2010). Rethinking accountability in a knowledge society. Journal of Educational Change, $11(1), 45-61$.

Salloum, S. J., Goddard, R. D., \& Berebitsky, D. (2018). Resources, learning, and policy: The relative effects of social and financial capital on student learning in schools. Journal of Education for Students Placed at Risk (JESPAR), 23(4), 281-303.

Scott, J. T. (2013). A Rosa Parks moment? School choice and the marketization of civil rights. Critical Studies in Education, 54(1), 5-18.

Shaw, C., \& Wright, S. (2000). Coercive accountability: The rise of audit culture in higher education. In M. Strathern (Ed.), Audit cultures: Anthropological studies in accountability, Ethics and the Academy (pp. 57-89). London: Routledge.

Steiner-Khamsi, G. (2013). What is wrong with the 'what-went-right' approach in educational policy? European Educational Research Journal, 12(1), 20-33.

Strathern, M. (Ed.). (2000). Audit cultures: Anthropological studies in accountability, ethics and the academy. London and New York: Routledge.

Tan, E. (2014). Human capital theory: A holistic criticism. Review of Educational Research, 84(3), 411-445.

Thiel, J. (2019). The UK National Student Survey: An amalgam of discipline and neo-liberal governmentality. British Educational Research Journal. https://doi.org/10.1002/berj.3512.

Tönnies, F. (2001[1887]). Community and Civil Society (J. Harris \& M. Hollis, Trans.), edited by Jose Harris. Cambridge: Cambridge University Press.

Tröhler, D. (2009). Globalizing globalization: The neo-institutional concept of a world culture. Yearbook of the National Society for the Study of Education, 108, 29-48.

Walzer, M. (2007). Thinking politically: Essays in political theory. New Haven, CT: Yale University Press (edited by David Miller).

Webb, P. T. (2006). The choreography of accountability. Journal of Education Policy, 21(2), 201-214.

Weber, M. (1947). The theory of social and economic organization, Edited by Talcott Parsons. New York: The Free Press, Macmillian Publishing Company.

Weiss, C. H. (1972). Evaluation research. Englewood Cliffs, NJ: Prentice-Hall.

West, A., Mattei, P., \& Roberts, J. (2011). Accountability and sanctions in English schools. British Journal of Educational Studies, 59(1), 41-62. https://doi.org/10.1080/00071005.2010.529416.

Wolf, A. (2004). Education and economic performance: Simplistic theories and their policy consequences. Oxford Review of Economic Policy, 20(2), 315-333.

Ydesen, C. (Ed.). (2019). The OECD's historical rise in education. The formation of a global governing complex. Switzerland: Palgrave McMillan.

Ydesen, C., \& Bomholt, A. (2019). Accountability implications of the OECD's economistic approach to education: A historical case analysis. Journal of Educational Change. https://doi.org/10.1007/s10833-01909355-1.

Publisher's Note Springer Nature remains neutral with regard to jurisdictional claims in published maps and institutional affiliations. 